\title{
Facilities and Location of Purchase Decisions at Supermarkets in Aceh
}

\author{
Saiful Amri ${ }^{1}$ \\ \{saiful.amri@gmail.com\} \\ 1) Lecturer at the Faculty of Economics Management, Serambi Mekkah Banda Aceh, Indonesia
}

\begin{abstract}
The purpose of this study was to determine whether facilities and locations affect the purchasing decisions at supermarkets in Aceh, the population in this study were customers who had bought at supermarkets in 2018. While the samples were taken 225 people or ten percent $(10 \%)$ of the total population by random sampling technique. Statistical test results of significant level of $\mathrm{F}$ test of 0,000 or $\mathrm{F}$ calculated value of 36,082 and $\mathrm{F}$ table at a significant level $=5 \%$ is $(3,369)$ so that it can be concluded that the calculated F value > Ftable the Quality of Service, Facilities and Location have influence on the purchase decision. In other words, $\mathrm{Ha}$ is accepted. The results of the research on the Influence of Service Quality, Facilities and Locations obtained t count value of Service Quality 4,841, Facility 2,567 and Location amounted to 6,656 towards the decision of buying obtained t value of 3,458 while t table was 1,987, the results of this calculation showed that $t$ count $>t$ table with a significance level of 0.000 thus the results of statistical calculations show that partially Service Quality, Facilities and Locations have an Influence on the Decision to Buy at Supermarkets. In other words, Ha is accepted.
\end{abstract}

Keywords: $\quad$ Satisfaction with Service, Facilities and Location

\section{Introduction}

Marketing is one of the main activities carried out by entrepreneurs to maintain their survival, to develop, and to make a profit. Marketing is developed from the word market which means or gathering place for people involved in marketing. In terms of abstract marketing is defined as an activity, process or whole system. Many things can affect the selfresignation of self-service businesses, one of which is how supermarkets can attract customers and maintain them by providing the best quality of service so that customers / consumers are satisfied with the services provided. In today's business competition, service is the most important thing for companies to differentiate strategies when they sell the same product. Good service will save. Unpleasant food, otherwise a tasty main dish does not guarantee and can save bad service. This proves that service quality is a very important aspect that must be considered by the company. Service quality is centered on meeting the needs and desires and the accuracy of delivery to offset customer expectations. The service here is all kinds of services provided by self-service parties as long as the customer is in the service, including the service provided by the service, and others. The development of business competition in Indonesia is one of the phenomena that is very interesting for us to see, especially with the 
globalization in the economic field that increasingly opens up opportunities for foreign entrepreneurs to compete in capturing local consumers. The impact of globalization has caused the service industry which consists of various industries such as the telecommunications industry, transportation, banking, which are developing rapidly. the local market as the host is increasingly required to recognize consumer behavior and then adjust the ability of the company to their needs. Companies that want to survive must have more value that makes the company different from other companies. The more value that is offered will further provide stability to prospective customers to transact or encourage old customers to make transactions again. The company in carrying out its business must always observe changes in consumer behavior so that it can anticipate these behavioral changes, to later become a study in order to improve its marketing strategy. In essence, the purpose of marketing is to know and understand the nature of consumers well so that the products offered can be sold. Consumer behavior is an individual activity that is directly involved in obtaining and using goods or services including the decision-making process in the preparation and determination of these activities self-service is a service industry that combines products and services. Building design, interior and existing facilities are examples of products offered. While the services sold are hospitality and the skills of self-service staff / employees in serving their customers. services as activities or benefits offered by one other party which are basically without form and do not produce any ownership. Supermarkets in Aceh have a strategic location for bakers and consumers who want to shop, because the supermarkets are located in the downtown area in less than 10 minutes and can be found also very easy for consumers who do not bring their personal vehicles to get public transportation. This is more value that makes many customers choose to buy at the nearest supermarket. security system that is equipped with CCTV, this also becomes a strength for the bakers to buy at the supermarket. Besides good service quality, facilities also play a role in capturing consumers. Facilities are facilities that make it easier for consumers to carry out an activity. Consumers today are critical consumers who are very careful in spending money. They consider many factors to choose a product or service, including for household needs. Facilities become one of the considerations of consumers in making choices. At almost the same price level, the more complete the facilities provided by the supermarket, the more satisfied the customer will be and he will continue to choose the company as a priority choice based on the perceptions he has of the available facilities.

\section{Research Methods}

\subsection{Location and Object of Research}

This research was conducted at supermarkets in Aceh, and the objects here are customers / consumers who transact in supermarkets.

\subsection{Population and Research Sample}

Population is the total number of units of analysis, namely the object to be studied (Bakar, 2004: 60). As for the population in this study are customers / consumers who have bought at supermarkets in 2018, so in determining the number of samples in this study using the Slovin formula quoted from Umar (2003: 49), with an average per day. 


\subsection{Data and Data Collection Techniques}

The type of data used in this study is primary data. Primary data is data obtained directly from the source of data collected specifically and directly related to the problem under study which is obtained directly from the respondent by field research. Data collection will be carried out using questionnaires that will be delivered and taken by researchers themselves to customers / consumers who are in supermarkets in Aceh.

\subsection{Validity and Reliability Testing}

Before the data is processed further, it must be tested for validity and reliability. Because the questionnaire as an instrument of data collection in this study must be tested for its validity and reliability. Tests are carried out to determine the consistency and accuracy of data collected from instrument users.

\subsection{Data Analysis Method}

To analyze the data, the method used is a simple linear regression method. This multiple linear regression is used to determine whether the independent variable has a significant and positive impact on the dependent variable. The regression equation is (Sugiono: 2005: 204):

$\mathrm{Y}=\mathrm{a}+\mathrm{b} \mathrm{X}_{1}+\mathrm{b} \mathrm{X}_{2}+\mathrm{b} \mathrm{X}_{3}+\mathrm{e}$

Where:

$$
\begin{array}{ll}
\mathrm{Y} & =\text { Purchase Decisions } \\
\mathrm{a} & =\text { Constants } \\
\mathrm{b} & =\text { Regression Coefficient } \\
\mathrm{X} & =\text { Service Quality } \\
\mathrm{X} 2 & =\text { Facility } \\
\mathrm{X} 3 & =\text { Location } \\
\mathrm{e} & =\text { Error }
\end{array}
$$

\subsection{Customer satisfaction}

Satisfaction and dissatisfaction of consumers become a hot topic discussed in various walks of life as well as industrial and service companies because customer satisfaction is determined by the quality of goods and services. Basically, the notion of satisfaction / dissatisfaction is the difference between expectations and perceived performance.

According to (Supranto, 2004), the definition of consumer satisfaction is as follows:

"The performance of an item is at least equal to what is expected by consumers, where essentially satisfaction measurement involves determining three factors, namely: 1). Choices about the right performance measurement, 2). Normative measurement process, and Instruments and 3). Measurement techniques used to create an indicator. "

In essence, every company engaged in a service company (service) recognizes three elements of competitive advantage, namely (Supranto, 2004):

a. Advantages of resources: includes skills and resources and funds.

b. Positional advantages; concerning the value for customers and lower costs.

c. Performance excellence includes customer satisfaction and loyalty, market share and profitability (profitability).

The three things mentioned above can be a priority, especially for companies engaged in the field of service marketing, both airlines, hospitals and ready-to-eat food products, so that each company is able to compete fairly and be able to capture a wider market share. 


\subsection{Definition of Service}

Services are often associated with service elements so that they are often referred to as service. (Winardi, 2003) provides an understanding of services, are:

Service is an activity or service activity held by a person or group of people to others. With the benefit of creating an activity by providing certain personal services, such as lawyer services, transportation, doctor, post office, hospitality, spectacle (cinema), telecommunications.

Furthermore Kotler (2007: 126) gives a definition of service is:

"Every activity or benefit offered by a party to another party and basically that is intangible, and does not result in ownership of a physical product".

In the above sense it can be concluded that service is an intangible activity, but it feels and is needed / needed. Service and quality are a means to achieve satisfaction and bond between a company / organization and customers. The purpose of a company / organization is not to produce quality products or services but rather to provide excellent service. This is intended to produce satisfied and loyal customers who will continue to establish business with the company. Therefore providing excellent service is a must if you want to achieve the goals of satisfied and loyal customers.

(Baduara \& Sirait, 2001) explain that: service or service contains the essence, "give service (service) with the best quality (quality) for your customers, so that marketing will appear in front of you".

Levitt (2000: 62) states that products are everything that is easy to see and has often been witnessed. Products can be tangible and intangible. Often the product is a combination of both.

\subsection{Service quality}

Quality is a word for service providers that is something that works well. Quality applications as the nature of product appearance or performance are a major part of a company's strategy in order to achieve sustainable excellence, either as a market leader or as a strategy to continue to grow. The quality problem is now not only the only weapon of competition but has become a "ticket to be paid" to enter the business world. Where the quality of a product / service is the extent to which the product / service meets its specifications.

\subsection{Consumer Service Behavior}

The main objective of marketers is to serve and satisfy the needs and desires of consumers. Therefore, marketers need to understand how consumer behavior satisfies their needs and desires. According to Solomon in Ari (2010: 25) Consumer behavior is the study of processes that occur when individuals or groups select, buy, use, or stop the use of products, services, ideas, or experiences in order to satisfy certain desires and desires. (Engel, 2002) states that consumer behavior is a direct action to get, consume, and spend products and services, including the decision process that precedes and follows this action Kotler and Armstrong in Ari (2010: 26) suggest that behavior consumers are the buying behavior of end consumers, both individuals and households who buy products for personal consumption. There are two important elements of consumer behavior, namely: (1) decision making process. (2) Physical activity, all of this involves individuals in assessing, obtaining and using economic goods or services. Based on the above understanding can be seen that consumer behavior is closely related to the decision making process to use goods or services to satisfy their needs and always act rationally. Consumers will try to maximize their satisfaction as long as their 
financial capabilities allow. They have knowledge of alternative products that can satisfy their needs. As long as the marginal utility obtained from purchasing products is still greater or equal to the costs that are sacrificed, consumers will tend to buy the products offered. In essence, the needs of consumers will experience changes in their lives in line with the social, economic and cultural changes that occur where they live. These changes will affect consumer behavior, namely in making purchasing decisions or using a product or service. Loudon and Blita in (Tjiptono, Chandra, \& Diana, 2004) suggest that consumer behavior is a process of decision making and the activities of individuals physically involved in evaluating, obtaining, wanting, choosing and using goods or services. There are several phases that consumers will pass before finally deciding to purchase services. The service purchase process is carried out through three phases, namely:

1. Pre purchase phase

Where decisions will be made in this phase. There are several factors that must be considered, including internal factors, external factors, factors of the company and risk..

2. The service counter

That is a situation where there is real interaction between consumers and service providers 3. Post Purchase phase

That is a situation where consumers will make an evaluation of the quality of services received, whether they are satisfied or not satisfied. For those who are satisfied, they will make a repeat purchase, the customer becomes loyal and will give positive word of mouth recommendations. But on the contrary, for consumers who are not satisfied, they will move to a service provider and will also provide negative word of mouth recommendations.

\subsection{Purchase Decision}

Purchase decisions are stages in the decision-making process where consumers decide to buy or not. According to Kotler In Ari (2005: 24) Here are theories about consumer decisions according to some experts According to Kotler (2005: 165) purchasing decisions are the stages of the buyer's decision process, that is, when consumers actually buy products Consumer decision making is a process of integration that combines knowledge to evaluate two or more alternative behaviors, and choose one of them. (Setiadi, 2003: 415)

Setiadi (2003: 27) states that there are five stages that consumers go through in the process of purchasing a service or product, namely product recognition, information seeking, alternative evaluation, purchasing decisions, and post-purchase behavior.

a. Product introduction is the process of starting when selecting goods or services by realizing many choices in obtaining the desired needs

b. Search information is to do as much information as is needed that is related to the desired or desired needs. This information search level is divided into two levels. The first level of attention is increased and the second is active information retrieval carried out by searching for information from all sources.

c. Alternative evaluation is that consumers process information about brand choices to make a final decision.

d. Consumers will look for certain benefits and then look at the attributes of the product or service. The purchase decision is that at this stage consumers make up the brands in the chosen set and form purchase intentions. And he will make choices with what he likes.

e. Post-purchase behavior is that consumers will experience two things, namely they will experience a level of satisfaction or dissatisfaction at all

According to Kotler (2003: 204) consumers pass through five stages in the process starting long before the actual purchase occurs and has consequences long after the purchase occurs. 
Each stage of the purchasing decision process. Actually, the purchase process can be explained as follows:

1. Introduction to Needs

he retrieval process begins when consumers recognize a need or problem. Consumers feel the difference between real and desired conditions. Needs can be triggered by internal stimuli when one person's normal needs, such as hunger and thirst appear at a level high enough to be an impulse. A need can also be triggered by external stimuli

2. Information Search

Consumers who are moved to their needs will be encouraged to find more information. We can divide it into two levels The lighter information search situation is called attention strengthening. At that level someone just becomes more sensitive to information about the product. At the next level, the person may enter an active search period of information. Through gathering information, consumers will find out about competing brands and the specialty of the brand. There are four groups that become sources of consumer information, namely:

a. Personal sources: family, friends, neighbors, and other acquaintances.

b. Commercial sources: advertising, salespeople, sellers, packaging and displays.

c. Public sources: mass media, consumer valuation organizations

d. Source of experience: handle, check, and use the product

3. Alternative evaluation

Some basic concepts will help us to understand the consumer evaluation process. First, consumers will try to meet a need. Second, consumers will seek certain benefits from product solutions. Third, consumers will view each product as a set of attributes with different abilities in providing benefits that are used to satisfy those needs. Consumers build trust in the brand regarding the position of each brand (brand positioning) in each attribute. A set of beliefs about a particular brand is known as a brand image. Brand image formed by consumers varies based on experience, and the effects of selective perception and selective retention.

4. Purchase Decision

In the evaluation stage, consumers form preferences for brands in a collection of choices. Consumers may also form intentions to buy a preferred product. But the following two factors can be between purchase intentions and purchasing decisions (purchasing decisions)

a. The first factor is the attitude of others. The extent to which other people's attitudes reduce alternatives that are preferred by someone will depend on two things, namely the intensity of the negative attitudes of others towards alternatives that consumers like, and the motivation of consumers to obey the wishes of others. The more aggressive the negative attitudes of others and the closer the person is to consumers, the greater the consumer will change his purchase intention, and vice versa.

b. The second factor is anticipated situation factors that can arise and can change purchase intentions. Consumers may form buying intentions based on factors such as estimated income, set prices, and expected product benefits. However, unanticipated events change the purchase intention.

5. Post-purchase behavior

After buying a product, consumers will experience a certain level of satisfaction or dissatisfaction. Marketers must monitor post-purchase product satisfaction, actions and use of post-purchase products. Purchasing satisfaction is a function of how close the buyer hopes to the product. Using alternatives that are selected and evaluate once again based on the resulting performance. The result of this process is that consumers will have a feeling of satisfaction or dissatisfaction with the product or service they consume. Satisfaction will encourage 
consumers to buy and re-consume the product. Conversely, feelings of dissatisfaction will make or cause consumers to be disappointed and stop buying back the product.

\section{$2.11 \quad$ Facilities}

According to Effendi in Ety (2006: 77), facilities are part of a product or service that is offered and sold to consumers, which is a consumer's right to be used, used, and enjoyed by consumers who purchase these products and services

\subsection{Location}

Lupiyoadi (2001: 27) states that location means that the company must be based and operate. In this case there are three types of interactions that affect location, namely:

1. Consumers come to service providers

If the situation is like this then the location becomes very important. Companies should choose places close to consumers so that they are easy to reach, in other words must be strategic..

2. Service providers visit consumers

In this case the location is not too important but what must be considered is the delivery of quality services. Providers and consumers do not meet directly. Means that service providers and consumers interact through certain means such as telephones, computers, or letters. in this case the location becomes very unimportant as long as communication between the two parties can be carried out.

According to Heizer and Render in Ari (2010: 24) the purpose of the location strategy is to maximize location benefits for the company. Location decisions often depend on the type of business. In the location analysis in the industrial sector, the strategy focused on cost minimization, while in the service sector, focus was aimed at maximizing income. This is because manufacturing companies find that costs tend to differ greatly between different locations, while service companies find that locations often have an income impact rather than costs. Therefore for specific location service companies it often affects income more than affects costs. This means that the location focus for service companies should be on determining business volume and revenue.

\section{Discussion Result}

\subsection{Relation of Service Quality, Facilities and Location to Purchase Decisions}

Service quality is described as an attitude from the results of comparison of service quality expectations with the company's perceived performance. Attitudes influence the decision to buy because of customer expectations or expectations. Furthermore, consumers form a behavior based on their previous expectations regarding company performance and this behavior affects their desire to buy, with good facilities that can shape perception in the eyes of customers. In a number of types of services, perceptions that are formed from interactions between customers and facilities affect the quality of service in the eyes of the customer that if a service company has adequate facilities so that it can facilitate consumers to use their services and make consumers comfortable using these services. consumers in purchasing services. In addition, companies that provide a pleasant atmosphere with attractive facility designs will influence consumers in making purchases. The choice of location for doing business must be done carefully. Although success does not only depend on the location of the 
business, but the location factor will affect the success of a business. Customers always consider shopping by looking at the appropriate location factors. So for that business people must consider strategic matters in determining location. Because the strategic location is related to the customer's purchasing decision to buy or use a product. To see the effect of service quality, facilities and location on purchasing decisions, the research will be seen from the influence of these variables as explained in the following table:

From the results of statistical calculations as shown in the table above, the regression equation is obtained as follows:

$\mathrm{Y}=1,037+0,311 \times 1+0.172 \times 2+0,335 \times 3$

- From the above equation can be seen the results of the study as follows:

- Correlation Coefficient (R) of 0.754 which indicates that the degree of relationship (correlation) between independent variables with the dependent variable is $75.4 \%$, meaning that Service Quality, Facilities and Location (x) have a close influence with the purchase decision (y).

- Determination Coefficient (R) of 0.568 means that $56.8 \%$ of changes in the dependent variable (Decision of Stay) can be explained by changes in Service Quality, Facilities and Location. Whereas the rest, which is $44.2 \%$, is explained by other variables outside this research.

- The constant is 1.037 means that Service Quality, Facilities and Location (x), are considered constant, then the amount of the Purchase decision is 1,037 on the Likert scale unit.

- Regresi Regression coefficient Service quality (x1) is 0.311 , Facility (x2) is 0.172 and Location (x3) is 0.335 , meaning that every $100 \%$ change (Service Quality, Facilities and Location) will relatively increase the Purchase decision, thus increasing high level of Service Quality, Facilities and Location (x), the greater the relationship in increasing the Purchase decision at Supermarkets.

\subsection{Validity Testing}

Data validity testing in this study was carried out statistically, that is, by using the Pearson product-moment coefficient of correlation test with the help declared valid because it has a significance level of below 5\%. Whereas if done manually, the correlation value obtained by each statement must be compared with the critical value of the product moment correlation where the results show that all statements have a correlation value above the critical value of $5 \%$ above (see Critical Value Table Product Moment $r$ correlation for $n=225$ In statistical language there is internal consistence which means that the statements measure the same aspect, this means that the data obtained is valid and can be used for research

\section{Conclusions}

Based on the results of the research and discussion in this study, the following conclusions were produced:

1. From the results of research and discussion, it can be concluded that: Test results show that the calculated F value > F table that Service Quality, Facilities and Location have influence on the Decision of Stay. In other words, Ha is accepted. And partially shows that $\mathrm{t}$ count $>\mathrm{t}$ table $5 \%$ thus the results of statistical calculations show that partially Service Quality, Facilities and Locations have an Influence on purchase decision. In other words, Ha is accepted.. 


\section{Recomendation}

Based on the limitations of the research described above, the research provides some suggestions for further research as follows: Adding a research variable so that it will cover more sub-variables so that research can be more convincing.

\section{Reference}

[1] Baduara, S., \& Sirait, S. M. (2001). Salesmanship, Suatu Ilmu dan Seni. Jakarta: Akademika Presindo.

[2] Engel, J. F. (2002). Custumer Behavior (6th ed.). Jakarta: Binarupa Aksara.

[3] Supranto, J. (2004). Pengukuran Tingkat Kepuasan Pelanggan. Jakarta: PT. Rineka Cipta.

[4] Tjiptono, F., Chandra, Y., \& Diana, A. (2004). Marketing Scales. Yogyakarta: Andi Offset.

[5] Winardi. (2003). Marketing dan Perilaku Konsumen. Jakarta: Mandar Maju.

[6] As'ad, Mohd (2000). Phisikologi Industri. Penerbit Liberty, Yogyakarta.

[7] Barry, Mason and Ezell (2002). Marketing Principle And strategy. Binarupa Aksara, Jakarta Barat, Indonesia.

[8] Boone dan Kurtz. (2000). Contemporary Marketing. Third Edition, The Dryden Press, USA.

[9] Birn, Robin J (2000) "The International Handbook of Market Research Technique" In Association with the Market Research Society (Kogan Page), London.

[10] Dabholkar, (2000) Toward An Understanding Of Loyalty: The Moderating Role Of Trust", Journal of Managerial Issues, Vol. IX no. 3.

[11] Dessler, Gary (2000). Manajemen Personalia. Terjemahan Agus Darma, Penerbit Erlangga, Jakarta.

[12] Drucker (2000). Mengelola Untuk Mencapai Hasil-Hasil Tugas-Tugas Ekonomi Dan Keputusan Mengambil Resiko. Yayasan Indonesia Emas, Institut Vincent dan PT. Gramedia Utama, Jakarta

[13] Februardi (2000). Pengukuran Kualitas Jasa (Service Quality) Bidang Pengajaran Yang disediakan oleh Politeknik Negeri Bandung. Jurnal Tata Niaga, Vol II, No 1. April.

[14] Gaspersz, Vincent, (2003) Membangun Tujuh Kebiasaan Kualitas Dalam Praktek Bisnis Global.Jakarta : Gramedia Pustaka.

[15] Soeprihanto, J. (2001). Manajemen Sumber Daya Manusia II. Jakarta: Karunia, Universitas Terbuka.

[16] Susanti (2007) Analisis Perbandingan Persepsi Konsumen Minimarket Indomaret Dengan Alfamart Di Komplek Cahaya Kemang Permai Kecamatan Pondok Gede Kota Bekasi”. Jurnal Ekonomi dan Bisnis, Vol 2 No 3.

[17] Supriyatmini (2005) Pengaruh Persepsi Nasabah Tentang Kualitas Pelayanan Terhadap Loyalitas Nasabah Pada Baitul Maal Wattamwil (Bmt) "Anda” Semarang. Jurnal Ekonomi dan Bisnis, Vol 1 No 4.

[18] Thorpe, (2000) The Management of Customer Contact Services Employees : An Empirical Investigation “, Journal of Marketing, Vol. 69.

[19] Wiyono, (2004) Perilaku Konsumen: Analisis Model Keputusan, Universitas Atma Jaya, Yogyakarta

[20] Zeithaml, V.A., Parasuraman, A. (2002) 'Problems and Strategies in Services Marketing' Journal of Marketing, 49: Spring, 33-46. 